\title{
PENGARUH PENGOLAHAN TANAH DAN APLIKASI HERBISIDA TERHADAP KANDUNGAN ASAM HUMAT PADA TANAH ULTISOL GEDUNG MENENG BANDAR LAMPUNG
}

\author{
Restu Yaasin Adi Putra, Sarno, Didin Wiharso \& Ainin Niswati \\ Jurusan Agroteknologi Fakultas Pertanian Universitas Lampung \\ J1. Sumantri Brojonegoro No 1 Bandar Lampung \\ E-mail: restuyasinadiputra@yahoo.com
}

\begin{abstract}
ABSTRAK
Tanah merupakan salah satu sumber daya alam yang penting perlu mendapat perhatian sungguh-sungguh agar terhindar dari kerusakan yang dapat menurunkan produktivitasnya. Kerusakan tanah dapat terjadi karena salah dalam pengolahaan. Aplikasi herbisida merupakan bagian tak terpisahkan yang dilakukan pada kegiatan pengolahan tanah sistem olah tanah intensif, akan berpengaruh terhadap aktivitas mikroorganisme tanah. Penurunan kandungan bahan organik di dalam tanah akibat praktik pengolahan tanah intensif mengakibatkan tanah menjadi tidak optimal dalam menunjang pertumbuhan tanaman dan kurang responsif terhadap pemupukan. Penelitian ini bertujuan untuk mengetahui pengaruh sistem olah tanah terhadap kandungan asam humat, untuk mengetahui pengaruh aplikasi herbisida terhadap kandungan asam humat, dan untuk mengatahui kombinasi sistem olah tanah dan aplikasi herbisid terhadap ketersediaan kandungan asam humat. Perlakuan disusun dalam Rancangan Acak Kelompok (RAK) dengan 4 perlakuan yaitu : Otm = olah tanah minimum; Otm+herbisida = olah tanah minimum+ herbisida yang berbahan aktif Glifosat 2,4- D; Ots = olah tanah sempurna; Ots+herbisida= olah tanah sempurna+herbisida yang berbahan aktif Glifosat 2,4- $D$ dan masing- masing perlakuan diulang sebanyak 4 kali sehingga terdapat 16 satuan percobaan. Rancangan perlakuan yang digunakan adalah faktorial. Masing- masing percobaan diterapkan pada petak percobaan yang berukuran $3 \mathrm{~m}$ x $4 \mathrm{~m}$. Homogenitas ragam diuji dengan uji Bartlet, aditivitas data diuji dengan uji Tukey. Jika asumsi terpenuhi data dianalisis dengan sidik ragam, perbedaan nilai tengah perlakuan diuji dengan uji Beda Nyata Terkecil (BNT) pada taraf 5\%. Selanjutnya dilakukan uji korelasi variabel utama yaitu C, N, P dan K. Hasil penelitian menunjukan bahwa perlakuan pengolahan tanah minimum memberikan pengaruh yang nyata lebih tinggi terhadap ketersediaan asam humat dibandingkan perlakuan pengolahan tanah sempurna. Perlakuan herbisida tidak memberikan pengaruh yang nyata terhadap ketersedi aan asam humat di dalam tanah. Perlakuan pengolahan tanah minimum dan tanpa herbisida memberikan pengaruh yang nyata lebih tinggi dibandingkan perlakuan lainnya terhadap ketersediaan asam humat.
\end{abstract}

Kata kunci: Aplikasi herbisida, asam humat, olah tanah minimum, olah tanah sempuna.

\section{PENDAHULUAN}

Tanah merupakan salah satu sumber daya alam yang penting perlu mendapat perhatian sungguh-sungguh agar terhindar dari kerusakan yang dapat menurunkan produktivitasnya. Kerusakan tanah dapat terjadi karena salah dalam pengelolaan. Banyak usaha yang dapat dilakukan untuk mempertahankan produktivitas tanah, salah satu diantaranya adalah melalui modifikasi cara olah tanah dan intensitas pengolahan tanah. Pengolahan tanah ialah kegiatan manipulasi mekanik terhadap tanah untuk menciptakan keadaan tanah yang baik bagi pertumbuhan tanaman. Berbagai sistem pengolahan tanah akan berpengaruh terhadap pemadatan tanah dan kandungan kadar bahan organik tanah (Fuady, 2010).

Pengolahan tanah dapat dilakukan dengan beberapa metode tergantung tingkat kepadatan tanah dan tingkat porositas tanah yang diinginkan. Pengolahan yang biasa dilakukan adalah olah tanh maksimum (konvensional), olah tanah minimum (OTM), dan tanpa olah tanah (TOT). Olah tanah minimum dan tanpa olah tanah biasanya dikelompokan ke dalam olah tanah konservasi (OTK) (Salam, 2012).

Pengolahan tanah untuk memperbaiki aerease tanah yang baik untuk perkembangan akar dan pertumbuhan tanaman. Pada umumnya dalam usaha tani tanaman pangan di lahan kering dilakukan olah tanah intensif sejak awal tanam tanpa memanfaatkan sisa tanaman, yang disebut juga pengolahan tanah konvensional. Selain membutuhkan waktu dan tenaga yang besar, pengolahan tanah konvensional dapat mempercepat kerusakan struktur dan komposisi bahan organik tanah, yang pada gilirannya akan meningkatkan laju erosi, terutama di lahan berlereng (Arsyad, 2001).

Olah tanah minimum (OTM) merupakan kegiatan olah tanah konservasi yang menggunakan sistem olah 
tanah secukupnya dengan mempertahankan sisa tanaman terdahulu masih ada di atas permukaan lahan tersebut (Prasetyo, 2014).

Aplikasi herbisida merupakan bagian tak terpisahkan yang dilakukan pada kegiatan pengolahan tanah sistem olah tanah intensif, akan berpengaruh terhadap aktivitas mikroorganisme tanah terutama jika campuran persenyawaan-persenyawaan itu diaplikasikan berulang kali selama bertahun-tahun. Menurut Dermiyati (1997) sebagian besar herbisida yang diaplikasikan ke tanaman akhirnya akan jatuh ke tanah, kemudian mengalami perubahan dan dalam waktu tertentu akan terjerap oleh fraksi liat dan bahan organik dalam tanah, yang secara umum dikenal sebagai residu herbisida. Residu herbisida beracun dalam tanah dapat membunuh mikroba tanah, yang sebenarnya bukan targetnya (non target microorganism) sehingga mengganggu aktivitas mikroorganisme tanah yang pada akhirnya dapat mempengaruhi siklus hara di dalam tanah.

Penurunan kandungan bahan organik di dalam tanah akibat praktik pengolahan tanah intensif mengakibatkan tanah menjadi tidak optimal dalam menunjang pertumbuhan tanaman dan kurang responsif terhadap pemupukan. Pengembalian sisa tanaman untuk meningkatkan kadar bahan organik tanah masih jarang dilakukan oleh sebagian besar petani. Sementara itu, dosis pupuk organik yang dibutuhkan cukup besar, umumnya mencapai kisaran ton per hektar. Hal tersebut dianggap kurang praktis bagi petani dalam mencari sumber pupuk organik dalam jumlah banyak maupun saat pemberiannya di lapang.

Penelitian ini bertujuan untuk mengetahui pengaruh sistem olah tanah terhadap kandungan asam humat, pengaruh aplikasi herbisida terhadap kandungan asam humat, dan mengetahui kombinasi sistem olah tanah dan aplikasi herbisida yang lebih efisien terhadap kandungan asam humat.

\section{BAHAN DAN METODE}

Penelitian ini dilaksanakan di Laboratorium Lapang Terpadu Fakultas Pertanian Universitas Lampung pada letak $5^{\circ} 22^{\prime} 10^{\prime \prime} \mathrm{LS}$ dan $105^{\circ} 14^{\prime} 38^{\prime \prime} \mathrm{BT}$ dengan ketinggian $146 \mathrm{~m}$ dpl (dari permukaan laut). Analisis tanah dilaksanakan di Laboratorium Ilmu Tanah Fakultas Pertanian Universitas Lampung dari bulan September 2014 sampai Agustus 2015.

Alat - alat yang digunakan adalah kantong plastik, sekop, ayakan $2 \mathrm{~mm}$, tabung film, spektrofotometer, sentrifius, alatpengaduk, dan alat-alat gelas untuk analisis tanah. Bahan yang digunakan adalah sampel tanah yang di ambil dari lokasi penelitian pada kedalaman $0-20 \mathrm{~cm}$ dan dikompositkan. Bahan kimia untuk menganalisis asam humat.

Perlakuan disusun dalam Rancangan Acak Kelompok (RAK) dengan 4 perlakuan yaitu : Otm = olah tanah minimum; Otm+herbisida = olah tanah minimum+ herbisida yang berbahan aktif Glifosat 2,4$D$; Ots = olah tanah sempurna; Ots+herbisida $=$ olah tanah sempurna+ herbisida yang berbahan aktif Glifosat 2,4- $D$ dan masing- masing perlakuan diulang sebanyak 4 kali sehingga terdapat 16 satuan percobaan. Rancangan perlakuan yang digunakan adalah faktorial. Masing- masing percobaan diterapkan pada petak percobaan yang berukuran $3 \mathrm{~m} \times 4 \mathrm{~m}$. Homogenitas ragam diuji dengan uji Bartlet, aditivitas data diuji dengan uji Tukey. Jika asumsi terpenuhi data dianalisis dengan sidik ragam, perbedaan nilai tengah perlakuan diuji dengan uji Beda Nyata Terkecil (BNT) pada taraf 5\%.

Pelaksanaan penelitian dilakukan dengan cara membuat petak percobaan secara berkelompok yaitu empat perlakuan pengolahan tanah dan pemberian herbisida. Petak percobaan pernah ditanami jagung dengan perlakuan yang sama pada bulan Maret - Juli 2014. Setelah itu, pada bulan juli 2014 ditanami dengan Ubi kayu (penelitian ini). Petak percobaan dibuat secara berkelompok yaitu empat perlakuan pengolahan tanah dan pemberian herbisida. Lahan penelitian dibagi menjadi 16 petak dengan ukuran setiap petaknya $3 \mathrm{~m} \times 4 \mathrm{~m}$ yang ditanami oleh tanamam ubi kayu dengan jarak tanam $90 \times 50 \mathrm{~cm}$. Tanaman ubi kayu ini dipupuk dengan pupuk Urea $200 \mathrm{~kg} \mathrm{ha}^{-1}$, SP-36 $300 \mathrm{~kg} \mathrm{ha}^{-1}$, KCL 300 $\mathrm{kg} \mathrm{ha}^{-1}$ dan Organonitrofos $10.000 \mathrm{~kg} \mathrm{ha}^{-1}$. Pupuk urea diberikan dua kali yaitu setengah dosis pada saat tanaman ubi kayu berumur satu minggu dan selanjutnya diberikan pada saat tanaman berumur 6 bulan. Sampel tanah diambil menggunakan sekop dari 5 titik pada masingmasing plot percobaan dengan kedalaman $20 \mathrm{~cm}$ dan kemudian dikompositkan. Pengambilan contoh awal dilakukan sebelum aplikasi herbisida yaitu pada tanggal 4 september 2014. Pengambilan contoh tanah kedua dilakukan pada 3 minggu setelah aplikasi herbisida. Variabel yang diamati adalah $\mathrm{pH}$ tanah, C-Organik (metode Walkley \& Black), dan Asam Humat (Watanabe dalam Sarno 1998).

\section{HASIL DAN PEMBAHASAN}

Hasil analisis ragam menunjukan bahwa perlakuan sistem olah tanah dan aplikasi herbisida tidak berbeda nyata terhadap $\mathrm{pH}$ tanah baik pada pengambilan bulan Agustus 2014, November 2014, maupun April 2015. Berdasarkan hasil penelitian nilai $\mathrm{pH}$ tanah pada sistem olah tanah dan aplikasi herbisida menunjukan bahwa nilai 
$\mathrm{pH}$ tanah tidak berpengaruh nyata terhadap sistem olah tanah dan aplikasi herbisida. Hal ini didukung oleh hasil penelitian Adnan (2012) yang menyatakan bahwa penerapan herbisida pada sistem TOT tidak menunjukan pengaruh yang nyata terhadap $\mathrm{pH}$ tanah dan $\mathrm{N}$-total, hal ini menunjukan bahwa jenis dan sistem olah tanah yang diterapkan sama-sama memiliki kemampuan dalam meningkatkan sifat kimia tanah tersebut. Menurut Nugroho (2013) bahan organik dapat menurunkan pH tanah tergantung tingkat kematangan dari bahan organik tersebut.

Hasil penelitian menunjukan bahwa perlakuan sistem olah tanah dan aplikasi herbisida tidak berbeda nyata terhadap kandungan C-Organik baik pada pengambilan bulan Agustus 2014, November 2014, maupun April 2015.

Berdasarkan hasil penelitian pada sistem olah tanah dan aplikasi herbisida terhadap kandungan COrganik berdasarkan analisis kimia menunjukan, bahwa kandungan C-Organik pada pengambilan bulan Agustus 2014 lebih tinggi nilainya dibandingkan kandungan COrganik pada bulan November 2014 dan bulan April 2015. Sehingga kandungan C-Organik tanah semakin menurun pada pengambilan kedua dan ketiga yang telah dilakukan pengolahan tanah serta aplikasi herbisida. Hasil analisis ragam diketahui bahwa sistem olah tanah dan aplikasi herbisida tidak berpengaruh nyata terhadap konsentrasi C-Organik. Hal ini didukung oleh hasil penelitian Burhannudin (2015) yang menunjukan bahwa sistem olah tanah dengan dan tanpa herbisida tidap berpengaruh nyata terhadap konsentrasi N-Total, K-dd, Ca-dd, Mg-dd, dan C-Organik yang dihasilkan. Menurut Arsyad (2001) terlihat bahwa C-Organik dan N-total tanah tanpa diolah lebih besar dibandingkan dengan tanah yang diolah secara intensif maupun minimum. Kondisi ini dikarenakan pada tanah yang diolah, dekomposisi bahan organik berjalan lebih cepat akibat aerase tanah dibandingkan tanah yang tidak diolah.

Hasil analisis ragam menunjukan bahwa perlakuan aplikasi herbisida tidak berpengaruh nyata terhadap kandungan Asam Humik pada pengambilan sample bulan Agustus 2014, November 2014, maupun April 2015. Sedangkan pada perlakuan sistem olah tanah berpengaruh nyata terhadap kandungan Asam Humik pada setiap pengambilan sample. Pengaruh Interaksi sistem olah tanah dan aplikasi herbisida berpengaruh nyata pada pengambilan sample bulan Agustus 2014 dan November 2014, sedangkan pada pengambilan sample bulan April 2015 tidak berpengaruh nyata terhadap kandungan Asam Humik.

Berdasarkan hasil penelitian pada sistem olah tanah dan aplikasi herbisida terhadap kandungan Asam
Humik berdasarkan analisis kimia menunjukan, bahwa Asam Humik pada pengambilan bulan Agustus 2014 lebih tinggi nilainya dibandingkan kandungan Asam Humik pada bulan November 2014 dan bulan April 2015 (Tabel 1).

Tabel 2 menunjukan bahwa pengaruh interaksi sistem olah tanah dan aplikasi herbisida terhadap kandungan asam humik pada bulan Agustus 2014 menunjukan pada tanpa herbisida kadar asam humik (AH) pada olah tanah intensif (OTI) nyata lebih rendah dibandingkan dengan olah tanah minimum (OTM),

Tabel 1. Pengaruh sistem olah tanah dan aplikasi herbisida terhadap asam humik tanah pada tanah Ultisol

\begin{tabular}{|c|c|c|c|}
\hline \multirow[b]{2}{*}{ Perlakuan } & \multicolumn{3}{|c|}{ Bulan } \\
\hline & $\begin{array}{c}\text { Agustus } \\
2014\end{array}$ & $\begin{array}{c}\text { November } \\
2014\end{array}$ & $\begin{array}{l}\text { April } \\
2015\end{array}$ \\
\hline & $\ldots \ldots \ldots \ldots$ & $\ldots \ldots \ldots$ & \\
\hline T0H0 & 59,02 & 56,66 & 54,46 \\
\hline T0H1 & 48,75 & 47,23 & 44,90 \\
\hline T1H0 & 37,73 & 35,99 & 33,98 \\
\hline T1H1 & 41,65 & 39,33 & 36,08 \\
\hline Total & 187,14 & 179,21 & 169,40 \\
\hline
\end{tabular}

Keterangan: $\mathrm{T} 0=$ Olah Tanah Minimum; $\mathrm{T} 1=$ Olah Tanah Intensif $; \mathrm{HO}=$ Tanpa Aplikasi Herbisida ; H1 = Aplikasi Herbisida

Tabel 2. Pengaruh interaksi sistem olah tanah dan aplikasi herbisida terhadap kandungan Asam Humik pada tanah Ultisol pada bulan Agustus 2014

\begin{tabular}{lcc}
\hline \multirow{2}{*}{$\begin{array}{c}\text { Sistem olah } \\
\text { tanah }\end{array}$} & \multicolumn{2}{c}{ Herbisida } \\
\cline { 2 - 3 } & $\begin{array}{c}\text { Tanpa } \\
\text { herbisida }\end{array}$ & $\begin{array}{c}\text { Dengan } \\
\text { herbisida }\end{array}$ \\
\hline \multirow{2}{*}{ Minimum } & $\ldots \ldots . .(\mathrm{mg} / \mathrm{g} \mathrm{C}$ tanah) $\ldots \ldots$ \\
& $59,02 \mathrm{~b}$ & $48,75 \mathrm{a}$ \\
Intensif & $\mathrm{B}$ & $\mathrm{A}$ \\
& $37,73 \mathrm{a}$ & $41,65 \mathrm{a}$ \\
& $\mathrm{A}$ & $\mathrm{A}$ \\
\hline BNT 0,05 & & 7,58 \\
\hline
\end{tabular}

Keterangan: Nilai Tengah yang diikuti dengan huruf yang sama pada arah horizontal (huruf kecil) atau vertikal (huruf besar) tidak berbeda nyata menurut uji BNT tarah $\alpha 5 \%$. 
sedangkan bila diaplikasikan herbisida kadar asam humik (AH) pada olah tanah minimum (OTM) lebih rendah tetapi tidak berbeda nyata dibandingkan dengan olah tanah intensif (OTI).

Tabel 3 menunjukan bahwa pengaruh interaksi sistem olah tanah dan aplikasi herbisida terhadap kandungan asam humik pada bulan November 2014 menunjukan pada tanpa herbisida kadar asam humik (AH) pada olah tanah intensif (OTI) nyata lebih rendah dibandingkan dengan olah tanah minimum (OTM), sedangkan bila diaplikasikan herbisida kadar asam humik (AH) pada olah tanah minimum (OTM) lebih rendah tetapi tidak berbeda nyata dibandingkan dengan olah tanah intensif (OTI).

Hasil penelitian menunjukkan bahwa kandungan asam humik berpengaruh nyata terhadap sistem Olah Tanah Minimum yaitu menunjukan bahwa kadar asam humik (AH) pada perlakuan tanpa herbisida dan olah tanah intensif (OTI) nyata lebih rendah dibandingkan dengan olah tanah minimum (OTM), sedangkan bila diaplikasikan herbisida kadar asam humik $(\mathrm{AH})$ pada olah tanah minimum (OTM) lebih rendah tetapi tidak berbeda nyata dibandingkan dengan olah tanah intensif (OTI). Hal ini didukung oleh hasil penelitian Sarno dkk. (1998) yang menunjukan bahwa fraksi asam humik pada sistem olah tanah minimum nyata lebih tinggi daripada olah tanah intensif. Menurut Niswati dkk. (1995) terdapat bahwa meskipun pada perlakuan tanpa olah digunakan herbisida, tetapi penggunaan herbisida tersebut tidak mempengaruhi mikroorganisme tanah, bahwa cendrung meningkatkan biomassa total tanah. Tingginya populasi mikroorganisme tanah pada sistem olah tanah konservasi tersebut mencerminkan semakin tingginya aktifitas mikroorganisme dalam mendekomposisi dan mensintesis kembali senyawa organik menjadi bahan humus tanah, akibatnya fraksi asam humik dan asam fulvik dan tingkat humifikasi pada sistem olah tanah konservasi meningkat. Karena sisasisa tanaman hanya dikembalikan pada permukaan saja dan aktifitas mikroorganisme lebih banyak terjadi pada permukaan tanah, maka fraksi asam humik dan fulvik lebih banyak terakumulasi dipermukaan tanah dan menurun menurut kedalaman.

Hasil analisis ragam menunjukan bahwa perlakuan sistem olah tanah dan aplikasi herbisida dapat diklasifikasikan tipe tingkat humifikasi tanah pada semua perlakuan termasuk dalam katagori tipe P. Hasil penelitian menunjukan tipe asam humik yang ditentukan dari nilai $\log \mathrm{K}$ dan RF pada pengambilan sample bulan Agustus 2014 yang memiliki jumlah rata-rata terendah 16,13 dan tertinggi 20,22 untuk nilai RF dan jumlah rata-rata terendah 0,57 dan tertinggi 0,63 untuk nilai $\log \mathrm{K}$. Dari kedua parameter ini dapat diklasifikasikan semua perlakuan termasuk dalam katagori tipe P. Pada pengambilan sample bulan November 2014 yang memiliki jumlah rata-rata terendah 15,56 dan tertinggi 18,55 untuk nilai RF dan jumlah ratarata terendah 0,61 dan tertinggi 0,67 untuk nilai $\log \mathrm{K}$. Dari kedua parameter ini dapat diklasifikasikan semua perlakuan termasuk dalam katagori tipe P. Pada pengambilan sample bulan April 2015 berkisar antara 15,48 sampai 17,33 untuk nilai RF dan 0,62 sampai 0,68 untuk nilai $\log \mathrm{K}$. Dari kedua parameter ini dapat diklasifikasikan hampir semua perlakuan termasuk dalam katagori tipe P (Tabel 4). Hal ini didukung oleh hasil penelitian Sarno (1998) sistem olah tanah lebih meningkatkan proses peningkatan humifikasi terhadap nilai $\log \mathrm{K}$ dan RF dibandingkan pemupukan N.

Menurut Kanonova dkk (1966) menyatakan bahwa terdapat sumber utama bahan humus tanah adalah berasal dari sisa-sisa tanaman dan hewan. Humifikasi sisa-sisa tanaman dan hewan tersebut akan terjadi tergantung pada komposisi kimia dan kondisi tanah yang mempengaruhi aktifitas mikroorganisme tanah. Peranan mikroorganisme tanah dalam proses dekomposisi adalah dalam jaringan tanaman dan mensintesis kembali dari senyawa organik menjadi bahan humus dengan bobot molekul lebih tinggi dan khas didalam tanah. Sehingga tingkat humifikasi dapat dipengaruhi oleh sistem olah tanah dan aplikasi herbisida.

Tabel 3. Pengaruh interaksi sistem olah tanah dan aplikasi herbisida terhadap kandungan Asam Humik pada tanah Ultisol pada bulan November 2014

\begin{tabular}{|c|c|c|}
\hline \multirow{2}{*}{$\begin{array}{l}\text { Sistem olah } \\
\text { tanah }\end{array}$} & \multicolumn{2}{|c|}{ Herbisida } \\
\hline & $\begin{array}{c}\text { Tanpa } \\
\text { herbisida }\end{array}$ & $\begin{array}{l}\text { Dengan } \\
\text { herbisida }\end{array}$ \\
\hline & \multicolumn{2}{|c|}{.......(mg/g C tanah $) \ldots \ldots$} \\
\hline \multirow[t]{2}{*}{ Minimum } & $56,66 \mathrm{~b}$ & $47,23 \mathrm{a}$ \\
\hline & B & A \\
\hline \multirow[t]{2}{*}{ Intensif } & 35,99 a & $39,33 \mathrm{a}$ \\
\hline & A & A \\
\hline BNT 0,05 & & 7,95 \\
\hline
\end{tabular}

Keterangan: Nilai Tengah yang diikuti dengan huruf yang sama pada arah horizontal (huruf kecil) atau vertikal (huruf besar) tidak berbeda nyata menurut uji BNT tarah $\alpha 5 \%$. 
Tabel 4. Pengaruh sistem olah tanah dan aplikasi herbisida terhadap tingkat humifikasi tanah pada tanah Ultisol.

\begin{tabular}{ccccc}
\hline Bulan & Perlakuan & RF & $\Delta$ Log K & Tipe \\
\hline \multirow{3}{*}{ Agustus } & T0H0 & 20,22 & 0,57 & $\mathrm{P}$ \\
2014 & T0H1 & 20,16 & 0,63 & $\mathrm{P}$ \\
& T1H0 & 18,12 & 0,58 & $\mathrm{P}$ \\
& T1H1 & 16,13 & 0,59 & $\mathrm{P}$ \\
November & T0H0 & 18,55 & 0,61 & $\mathrm{P}$ \\
2014 & T0H1 & 18,30 & 0,67 & $\mathrm{P}$ \\
& T1H0 & 17,33 & 0,65 & $\mathrm{P}$ \\
\multirow{2}{*}{ April } & T1H1 & 15,56 & 0,67 & $\mathrm{P}$ \\
& T0H0 & 17,33 & 0,68 & $\mathrm{P}$ \\
& T0H1 & 17,24 & 0,66 & $\mathrm{P}$ \\
& T1H0 & 17,23 & 0,63 & $\mathrm{P}$ \\
& T1H1 & 15,48 & 0,62 & $\mathrm{P}$ \\
\hline
\end{tabular}

Keterangan: $\mathrm{T} 0=$ Olah Tanah Minimum; $\mathrm{T} 1=$ Olah Tanah Intensif ; $\mathrm{H} 0=$ Tanpa Aplikasi Herbisida $; \mathrm{H} 1$ = Aplikasi Herbisida

\section{KESIMPULAN}

Berdasarkan penelitian yang telah dilaksanakan, dapat disimpulkan bahwa perlakuan pengolahan tanah minimum memberikan pengaruh yang nyata lebih tinggi terhadap ketersediaan asam humat dibandingkan perlakuan pengolahan tanah sempurna. Perlakuan herbisida tidak memberikan pengaruh yang nyata terhadap ketersedi aan asam humat di dalam tanah. Perlakuan pengolahan tanah minimum dan tanpa herbisida memberikan pengaruh yang nyata lebih tinggi dibandingkan perlakuan lainnya terhadap ketersediaan asam humat.

\section{DAFTAR PUSTAKA}

Adnan, Hasanuddin, dan Manfarizah. 2012. Aplikasi beberapa dosis herbisida glifosat dan paraquat pada sistem tanpa olah tanah (TOT) serta pengaruhnya terhadap sifat kimia tanah, karakteristik gulma dan hasil kedelai. J. Agrista 16(3): 135-145.

Arsyad, A.R. 2001. Pengaruh olah tanah konservasi dan olah tanam terhadap sifat fisika tanah Ultisol dan hasil jagung. J. Agronomi. 8(2):111-116.

Burhannudin. 2015. Pengaruh sistem olah tanah dan herbisida terhadap kehilangan unsur hara dan bahan organik akibat erosi di Laboratorium Lapang Terpadu Fakultas
Pertanian Universitas Lampung. J. Teknik Pertanian Lampung. 3(3): 275-282.

Dermiyati. 1997. Pengaruh mulsa terhadap aktivitas mikroorganisme tanah dan produksi jagung hibrida C-1. J.Tanah Trop. 5: 63-68.

Fuady, Z. 2010. Pengaruh sistem olah tanah dan residu tanaman terhadap laju mineralisasi nitrogen tanah. J. Ilmiah Sains dan Teknologi 10(1): 94-101.

Kononova, M.M., T.Z. Nowaski, dan A.C.D. Newman. 1966. Soil Organic Metter. $2^{\text {nd }}$ Ed. Pergamon Press. Oxford. 544 p. dalam Sarno, S. Yusnaini, Dermiyati, dan M. Utomo. 1998. Pengaruh sistem olah tanah dan pemupukan nitrogen jangka panjang terhadap kandungan asam humik dan fulvik. J. Tanah Tropika 7: 35-42.

Mukhlis, H. 2004. Cara Penyiapan Lahan dan Mikroba Tanah dalam Budidaya Pertanian. Balai Penelitian Pertanian Lahan Rawa. Kalimantan Selatan. dalam Burhannudin. 2015. Pengaruh sistem olah tanah dan herbisida terhadap kehilangan unsur hara dan bahan organik akibat erosi di Laboratorium Lapang Terpadu Fakultas Pertanian Universitas Lampung. J. Teknik Pertanian Lampung 3 (3) : 275-282.

Niswati, A., S.G. Nugroho, dan M. Utomo. 1995. Pengaruh Aplikasi Herbisida Glifosat Terus Menerus Selama Lima Belas Musim Dalam Praktik Budidaya Tanpa Olah Tanah Terhadap Populasi Mikroba Tanah. Pros. Sem Nas., V BDP OTK, Bandar Lampung, 1995. Hlm. 140-148. dalam Sarno, S. Yusnaini, Dermiyati, dan M. Utomo. 1998. Pengaruh sistem olah tanah dan pemupukan nitrogen jangka panjang terhadap kandungan asam humik dan fulvik. J. Tanah Tropika 7: 35-42.

Prasetyo dkk. 2014. Pengaruh sistem olah tanah dan berbagai mulsa organik pada pertumbuhan dan hasil tanaman kedelai (Glycine max (L.) Merr.) var. grobogan. J. Produksi Tanaman. 1(6): 486-495.

Salam. A.K. 2012. Ilmu Tanah Fundamental. Penerbit Global Madani Press. Bandar Lampung. 362 hlm.

Sarno, S. Yusnaini, Dermiyati, dan M. Utomo. 1998. Pengaruh sistem olah tanah dan pemupukan nitrogen jangka panjang terhadap kandungan asam humik dan fulvik. J. Tanah Tropika. 7: 35-42. 
Sarno. 2004. Peranan Bahan Organik dalam Meningkatkan Kesuburan dan Produktivitas Tanaman. Disampaikan pada: Pelatihan Petugas Pemandu Lapang 1 (PL-1) Pengembangan Agribisnis Hortikultura Tahun Anggaran 2004. Bandar Lampung. 9 hlm.
Stevenson, F.J. 1982. Humus Chemistry: Genesis, compotition, reactions. Jhon Wiley and Sqons, Inc, Second edition. New York. $496 \mathrm{hlm}$. dalam: Interaksi Mineral Tanah Dengan Bahan Organik Alami dan Mikroba. Diterjemahkan Oleh Didiek H. Goenadi, 1997. Gadjah Mada University Press. 